\title{
Tomitella biformata gen. nov., sp. nov., a new member of the suborder Corynebacterineae isolated from a permafrost ice wedge
}

\author{
Correspondence \\ Kozo Asano \\ asanok@chem.agr.hokudai.ac.jp
}

\author{
Taiki Katayama, ${ }^{1} \dagger$ Tomoko Kato, ${ }^{1}$ Michiko Tanaka, ${ }^{1}$ Thomas A. Douglas, ${ }^{2}$ \\ Anatoli Brouchkov, ${ }^{3}$ Ayumi Abe, ${ }^{1}$ Teruo Sone, ${ }^{1}$ Masami Fukuda ${ }^{4}$ \\ and Kozo Asano ${ }^{1}$
}
${ }^{1}$ Laboratory of Applied Microbiology, Graduate School of Agriculture, Hokkaido University, N9 W9 Kita-ku, Hokkaido 060-8589, Japan
${ }^{2}$ Cold Regions Research and Engineering Laboratory, Fort Wainwright, AK 99703-0170, USA
${ }^{3}$ Tyumen State Oil and Gas University, Tyumen Scientific Center, Siberian Branch of Russian Academy of Sciences, 86 Malygin St, Tyumen 625048, Russia
${ }^{4}$ International Arctic Research Center, University of Alaska, Fairbanks, AK 99775-7340, USA

At the time of writing, actinomycetes that are characterized by the presence of mycolic acids and cell wall chemotype IV

tPresent address: Research Institute of Genome-based Biofactory, National Institute of Advanced Industrial Science and Technology, 2-172-1, Tsukisamu-higashi, Toyohira-ku, Hokkaido 062-8517, Japan.

The GenBank/EMBL/DDBJ accession numbers for the 16S rRNA, gyr $B, r p o B$ and rec $A$ gene sequences of strains $A H U 1821^{\top}$ and AHU1820 are AB491283 and AB491284 (16S rRNA), AB491285 and AB491286 (gyrB), AB491287 and AB491288 (rpoB) and AB491289 and AB491290 (recA), respectively.

A scanning electron micrograph of cells of strain $\mathrm{AHU}_{1821^{\top}}$, a neighbour-joining tree showing the relationship between strains AHU182 $1^{\top}$ and AHU1820 and other mycolic-acid-containing bacteria and images of $\mathrm{AHU} 1821^{\top}$ and $\mathrm{AHU} 1820$ colony morphology are available as supplementary material with the online version of this paper.
(Lechevalier \& Lechevalier, 1970) include the genera Corynebacterium, Dietzia, Gordonia, Millisia, Mycobacterium, Nocardia, Rhodococcus, Segniliparus, Skermania, Smaragdicoccus, Tsukamurella and Williamsia within the suborder Corynebacterineae (Butler et al., 2005; Goodfellow \& Maldonado, 2006; Soddell et al., 2006; Adachi et al., 2007). Members of this suborder are distinguished from those of other suborders by their phylogeny, based on 16S rRNA gene sequence analysis, and their phenotypic properties.

Previously, we reported on the isolation of bacteria that had been preserved within a permafrost ice wedge for $\sim 25000$ years (Katayama et al., 2007). Phylogenetic analysis based on $16 \mathrm{~S}$ rRNA gene sequences indicated that two of the ice-wedge isolates, namely strains AHU1821 ${ }^{\mathrm{T}}$ and AHU1820, were distinct from genera within the 
suborder Corynebacterineae. In this paper, we describe these two strains further and suggest that they represent a novel genus and species in the suborder Corynebacterineae.

Strains AHU182 $1^{\mathrm{T}}$ and AHU1820 were isolated from an ice wedge in the Fox permafrost tunnel, Alaska, USA $\left(64.952^{\circ}\right.$ $\mathrm{N} 147.617^{\circ} \mathrm{W}$ ), which is preserved at about $-3{ }^{\circ} \mathrm{C}$ by the US Army's Cold Regions Research and Engineering Laboratory. Sample collection and laboratory isolation methods have been described previously (Katayama et al., 2007). Strains AHU $1821^{\mathrm{T}}$ and AHU1820 were originally isolated on agar plates containing Hickey-Tresner revised medium with antibiotics. The strains grew well aerobically at $20{ }^{\circ} \mathrm{C}$ in tryptic soy broth (TSB) supplemented with $2 \%$ $(\mathrm{w} / \mathrm{v})$ D-fructose or $2 \%(\mathrm{v} / \mathrm{v})$ ethanol. Cell cultures used for all experiments were prepared in TSB with $2 \%$ Dfructose at $20{ }^{\circ} \mathrm{C}$ unless indicated otherwise.

The 16S rRNA, gyrB, rpoB and recA gene sequences of strains AHU1821 ${ }^{\mathrm{T}}$ and AHU1820 were determined. The lengths of the gene sequences were $1471 \mathrm{bp}$ for the $16 \mathrm{~S}$ rRNA gene (Escherichia coli positions 28-1522), $1506 \mathrm{bp}$ for gyrB [Nocardia farcinica IFM 10152 (GenBank accession no. NC_006361) positions $172-1671 ; 72.0 \%$ of the total length], $2892 \mathrm{bp}$ for $r p o B$ ( $N$. farcinica IFM 10152 positions 436-3321;82.9\%) and $902 \mathrm{bp}$ for recA (N. farcinica IFM 10152 positions $76-977 ; 86.4 \%$ ). Phylogenetic analyses and physical and chemotaxonomic characterizations were performed according to methods described previously (Katayama et al., 2009).

Cell morphology was observed under a scanning electron microscope (JOEL, JSM-6301F) (Supplementary Fig. S1, available in IJSEM Online). Growth at $-5,15,20,23$ and $25{ }^{\circ} \mathrm{C}$ was determined based on increase in $\mathrm{OD}_{600}$. The upper temperature limit for growth was determined from colony formation at $25,27,30$ and $37^{\circ} \mathrm{C}$ on tryptic soy agar (TSA) supplemented with $2 \% \mathrm{D}$-fructose. Growth at $\mathrm{pH} 4.0-11.5$, at intervals of $0.5 \mathrm{pH}$ units, was examined by culturing cells on TSB supplemented with $0.5 \%$ D-fructose. Enzyme activities were determined using the commercial API ZYM system (bioMérieux). Analysis of whole-cell sugars and the detection of diaminopimelic acid were performed according to the method of Staneck \& Roberts (1974). Polar lipids were extracted and identified by twodimensional TLC (Minnikin et al., 1984). Mycolic acids were extracted and analysed using GC-MS (QP2010; Shimadzu) as described by Yano et al. (1972).

The 16S rRNA, rpoB and recA gene sequences of strains AHU182 $1^{\mathrm{T}}$ and AHU1820 were identical and the gyrB gene sequences showed $99.9 \%$ similarity (1 nt difference). The two strains showed less than $97 \% 16 \mathrm{~S}$ rRNA gene sequence similarity with the members of the suborder Corynebacterineae. They were also related to Rhodococcus coprophilus (95.6\% similarity to the type strain) and other members of the genus Rhodococcus $(95.4 \%-92.3 \%)$ and to members of the genera Nocardia (94.9\% and lower) and Tsukamurella (94.8\% and lower). Based on gyrB gene sequences, the ice-wedge isolates were related to Rhodococcus equi $(82.7 \%$ gyrB gene sequence similarity to the type strain), Nocardia neocaledoniensis $(82.6 \%)$ and Nocardia thailandica $(82.5 \%)$. The neighbour-joining trees based on $16 \mathrm{~S}$ rRNA and $g y r B$ gene sequences indicated that the icewedge isolates formed a monophyletic branch distinct from members of the suborder Corynebacterineae (Fig. 1 and Supplementary Fig. S2). The DNA G $+\mathrm{C}$ contents of strains AHU1821 $1^{\mathrm{T}}$ and AHU1820 were 69.3 and $71.6 \mathrm{~mol} \%$, respectively.

Physiological and morphological characteristics common to strains AHU1821 ${ }^{\mathrm{T}}$ and AHU1820 are given in the genus and species descriptions below. No differences were evident between the two strains except for their colony morphology. When grown on TSA supplemented with $2 \%$ Dfructose, the colonies of strain AHU $1821^{\mathrm{T}}$ were circular with entire margins that were smooth, convex and beige, whereas the colonies of strain AHU1820 were circular with an undulating edge, dry, flat and beige (Supplementary Fig. S3).

The predominant menaquinone in both $\mathrm{AHU} 1821^{\mathrm{T}}$ and AHU1820 was MK-9 $\left(\mathrm{H}_{2}\right)$, which is different from that of the related genera Rhodococcus, Nocardia and Tsukamurella (Table 1). Minor amounts of MK-10( $\left.\mathrm{H}_{2}\right)$ (3\% of total menaquinones) and MK-8 $\left(\mathrm{H}_{2}\right)(1 \%)$ were also present. Muramic acid residues in the peptidoglycans of the strains AHU182 $1^{\mathrm{T}}$ and AHU1820 were glycolated. Whole-cell hydrolysates of strains AHU1821 ${ }^{\mathrm{T}}$ and AHU1820 included the diamino acid meso-diaminopimelic acid and the sugars arabinose, galactose, glucose and ribose, indicating wall chemotype IV. The polar lipids detected in strains AHU182 $1^{\mathrm{T}}$ and AHU1820 included diphosphatidylglycerol, phosphatidylethanolamine, phosphatidylinositol, phosphatidylinositol mannosides and an unidentified glycolipid. Cells of strains AHU1821 ${ }^{\mathrm{T}}$ and AHU1820 contained mycolic acids with between 42 and 52 carbons. Fatty acids found in cells of strain AHU182 $1^{\mathrm{T}}$ cultured at $15{ }^{\circ} \mathrm{C}$ were $\mathrm{C}_{16: 1}(39.8 \%), \mathrm{C}_{16: 0}(23.0 \%), \mathrm{C}_{18: 1}(20.1 \%)$ and $\mathrm{C}_{14: 0}(9.9 \%)$. Tuberculostearic acid (10-methyl $\mathrm{C}_{18: 0}$ ), which is a major fatty acid component in related genera Rhodococcus, Nocardia and Tsukamurella (Goodfellow \& Maldonado, 2006), was present in relatively small amounts ( $1 \%$ and lower) in strain AHU1821 ${ }^{\mathrm{T}}$. Small proportions or the absence of methyl-branched fatty acids were seen in the distantly related genera Corynebacterium, Millisia and Smaragdicoccus (Soddell et al., 2006; Adachi et al., 2007). In GC-MS analysis, two peaks of $\mathrm{C}_{16: 1}$, $\mathrm{A}$ and $\mathrm{B}$ (Supplementary Table S1), were obtained. The size of both peaks was strongly dependent on growth temperature. The proportion of $\mathrm{C}_{16: 1} \mathrm{~A}$ increased with decreasing temperature, while that of $\mathrm{C}_{16: 1} \mathrm{~B}$ decreased with decreasing temperature. In general, to maintain membrane fluidity at low temperatures, bacteria alter their fatty acid profiles by increasing the cellular proportion of fatty acids that have a lower melting point (Gounot \& Russell, 1999). Cis fatty acids have a lower phase transition temperature than their corresponding trans isomers (Keweloh \& Heipieper, 1996), suggesting that $\mathrm{C}_{16: 1} \mathrm{~A}$ and $\mathrm{B}$ might be in the cis and trans configurations, 


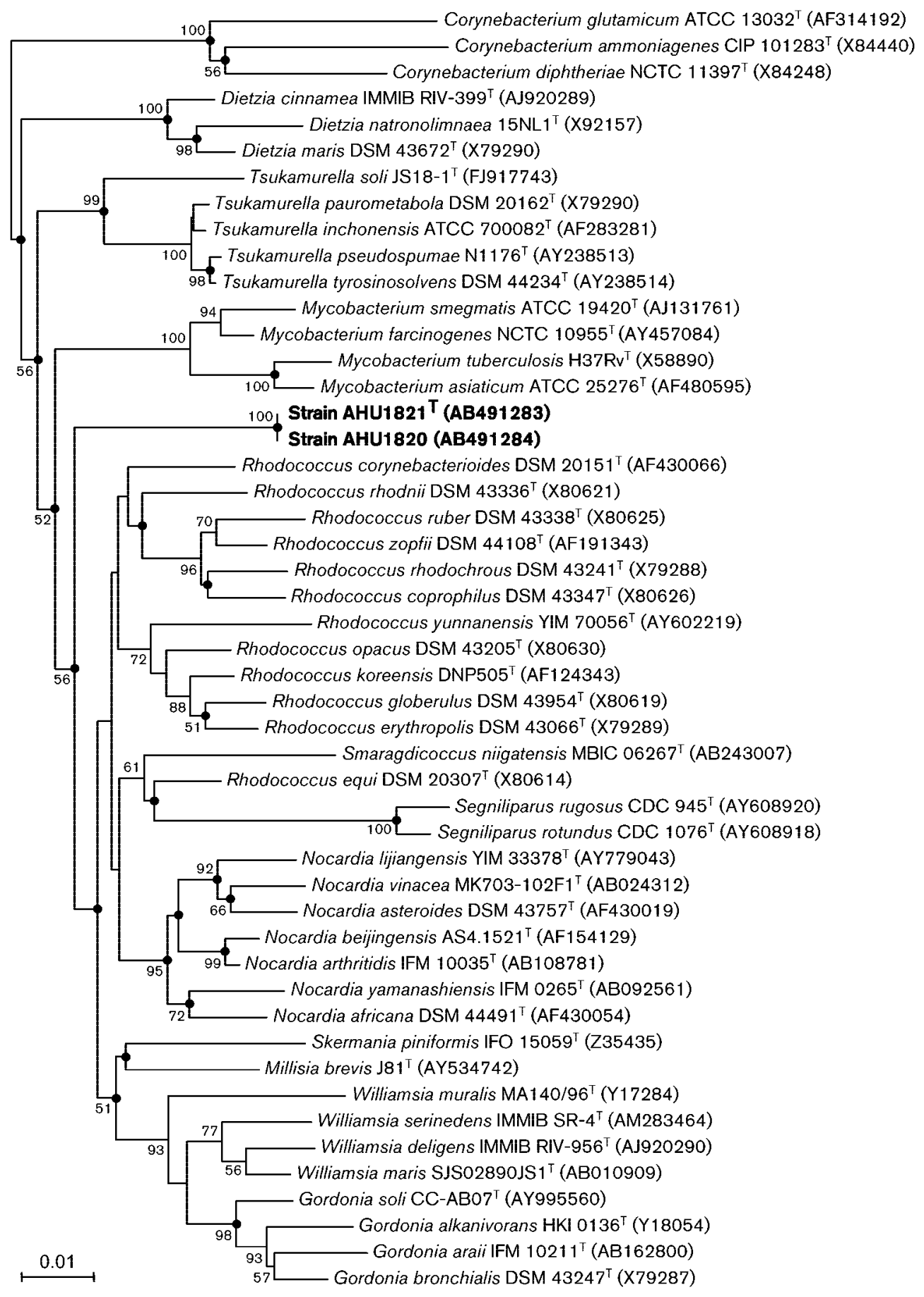

Fig. 1. Neighbour-joining tree showing the relationship between strains $A H U 1821^{\top}$ and AHU1820 and other mycolic acidcontaining bacteria. Bootstrap values $>50 \%$ are shown at nodes. Dots indicate branches that were also found in the maximumlikelihood tree. Bar, 0.01 substitutions per nucleotide position.

respectively. The fatty acid profile and its temperature dependence were almost identical between strains AHU $1821^{\mathrm{T}}$ and AHU1820.

The $16 \mathrm{~S}$ rRNA and gyrB gene trees and the phenotypic characteristics indicated that the strains $\mathrm{AHU} 1821^{\mathrm{T}}$ and
AHU1820 are clearly distinct from the genera within the suborder Corynebacterineae. To evaluate the genomic relatedness between strains AHU182 $1^{\mathrm{T}}$ and AHU1820, we compared the sequences of $g y r B, r p o B$ and recA genes as well as those of the 16S rRNA gene, as described above. In a recent study by Adékambi et al. (2008), the intraspecific 
Table 1. Chemical properties of strains AHU1821 ${ }^{\top}$ and $A H U 1820$ and other mycolic acid-containing genera

Data for established genera were taken from the following studies: Segniliparus, Butler et al. (2005); Smaragdicoccus, Adachi et al. (2007); Millisia, Soddell et al. (2006); other genera, Goodfellow \& Maldonado (2006). SQA, Smaragdiquinone A; SQB, smaragdiquinone B; G, glycolated; A, acetylated; PE, phosphatidylethanolamine; s, saturated fatty acid; U, unsaturated fatty acid; T, tuberculostearic acid; ND, no data.

\begin{tabular}{|c|c|c|c|c|c|c|}
\hline Strain or genus & Predominant menaquinone(s) & $\begin{array}{l}\text { Acyl } \\
\text { type }\end{array}$ & PE & $\begin{array}{l}\text { Major fatty } \\
\text { acids }\end{array}$ & $\begin{array}{c}\text { Mycolic acids } \\
\text { (no. of carbons) }\end{array}$ & $\begin{array}{c}\text { DNA G + C } \\
\text { content }(\mathrm{mol} \%)\end{array}$ \\
\hline $\begin{array}{l}\text { Strains AHU1821 } \\
\text { and AHU1820 }\end{array}$ & $\operatorname{MK}-9\left(\mathrm{H}_{2}\right)$ & G & + & $\mathrm{s}, \mathrm{U}$ & $42-52$ & $69.3-71.6$ \\
\hline Corynebacterium & MK-8 $\left(\mathrm{H}_{2}\right),-9\left(\mathrm{H}_{2}\right)$ & A & - & S, U & $22-38$ & $51-63$ \\
\hline Dietzia & $\mathrm{MK}-8\left(\mathrm{H}_{2}\right)$ & A & - & $\mathrm{S}, \mathrm{U}, \mathrm{T}$ & $34-38$ & 73 \\
\hline Tsukamurella & MK-9 & G & + & $\mathrm{S}, \mathrm{U}, \mathrm{T}$ & $64-78$ & $67-78$ \\
\hline Mycobacterium & MK-9 $\left(\mathrm{H}_{2}\right)$ & G & + & $\mathrm{S}, \mathrm{U}, \mathrm{T}$ & $60-90$ & $62-70$ \\
\hline Rhodococcus & MK-8 $\left(\mathrm{H}_{2}\right)$ & G & + & $\mathrm{S}, \mathrm{U}, \mathrm{T}$ & $30-54$ & $63-73$ \\
\hline Nocardia & MK-8 $\left(\mathrm{H}_{4}, \omega\right.$-cycl. $)$ & G & + & $\mathrm{S}, \mathrm{U}, \mathrm{T}$ & $48-60$ & $64-72$ \\
\hline Smaragdicoccus & $\begin{array}{l}\text { SQA- } 8\left(\mathrm{H}_{4}, \omega \text {-cycl. }\right), \text { SQB- } 8\left(\mathrm{H}_{4} \text {, }\right. \\
\text { dicycl. })\end{array}$ & G & + & $S, \mathrm{U}$ & $43-49$ & 63.7 \\
\hline Segniliparus & $\mathrm{ND}$ & ND & ND & $\mathrm{S}, \mathrm{U}, \mathrm{T}$ & ND & $68-72$ \\
\hline Gordonia & MK-9 $\left(\mathrm{H}_{2}\right)$ & G & + & $\mathrm{S}, \mathrm{U}, \mathrm{T}$ & $46-66$ & $60-66$ \\
\hline Williamsia & MK-9 $\left(\mathrm{H}_{2}\right)$ & G & + & $\mathrm{S}, \mathrm{U}, \mathrm{T}$ & $50-56$ & $64-65$ \\
\hline Skermania & MK- $8\left(\mathrm{H}_{4}, \omega\right.$-cycl. $)$ & G & + & $\mathrm{S}, \mathrm{U}, \mathrm{T}$ & $58-64$ & 67.5 \\
\hline Millisia & MK- $8\left(\mathrm{H}_{2}\right)$ & G & + & $S, \mathrm{U}$ & $44-52$ & 64.7 \\
\hline
\end{tabular}

$r p o B$ sequence similarity was estimated to be between 98.2 and $100 \%$ by correlation with DNA-DNA relatedness analysis. These data strongly support the genomic consistency between the two strains. Accordingly, the strains AHU182 $1^{\mathrm{T}}$ and AHU1820 represent a single novel genus and species, for which the name Tomitella biformata gen. nov., sp. nov. is proposed.

On the basis of $16 \mathrm{~S}$ rRNA signature nucleotide patterns, which were updated by Zhi et al. (2009), Tomitella biformata strains were affiliated with the family Tsukamurellaceae in the suborder Corynebacterineae. However, the 16S rRNA gene tree indicates that the two Tomitella strains form a clade distinct from members of the family Tsukamurellaceae. Further comparative taxonomic studies on additional Tomitella strains are needed to determine the family assignment.

\section{Description of Tomitella gen. nov.}

Tomitella (To.mi.tel'la. N.L. fem. n. Tomitella named in honour of Emeritus Professor Fusao Tomita, a celebrated Japanese microbiologist).

Cells are aerobic, Gram reaction-positive, non-sporeforming, irregular rods. The predominant quinone is a dihydrogenated menaquinone with nine isoprene units. Whole-cell hydrolysates are rich in meso-diaminopimelic acid, arabinose and galactose. The muramic acid residues are glycolated. The polar lipids detected include diphosphatidylglycerol, phosphatidylethanolamine, phosphatidylinositol, phosphatidylinositol mannosides and an unidentified glycolipid. Mycolic acids are present with between 42 and 52 carbon atoms. $\mathrm{C}_{16: 1}, \mathrm{C}_{16: 0}, \mathrm{C}_{18: 1}$ and
$\mathrm{C}_{14: 0}$ are the major fatty acids. $10-$ methyl- $\mathrm{C}_{18: 0}$ is present in relatively small proportions. The DNA G $+\mathrm{C}$ content of the type strain of the type species is $69.3 \mathrm{~mol} \%\left(T_{\mathrm{m}}\right)$. The type species is Tomitella biformata.

\section{Description of Tomitella biformata sp. nov.}

Tomitella biformata (bi.for.ma'ta. L. fem. adj. biformata two-shaped).

Has the following characteristics in addition to those given for the genus. Cells exhibit snapping division and produce V-forms. Cells turn into short coccoid rods after prolonged culture. On TSA supplemented with $2 \% \mathrm{D}-$ fructose colonies are circular with smooth entire margins, convex and beige, or colonies are circular with an undulating edge, dry, flat and beige. Grows at -5 to $27{ }^{\circ} \mathrm{C}$ and at $\mathrm{pH} 5-10$. The optimal temperature for growth is $20{ }^{\circ} \mathrm{C}$. Catalase-positive and oxidase-negative. Acid is produced from D-fructose, glycerol and ethanol and is produced weakly from D-mannose, but not from D- or L-arabinose, D-galactose, D-glucose, L-rhamnose, D-xylose, D-ribose, cellobiose, maltose, sucrose, turanose, D- or L-fucose, D- or L-xylose, trehalose, raffinose, D-sorbitol, D-mannitol, xylitol, starch or inulin. Positive for alkaline phosphatase, acid phosphatase, esterase lipase $\left(\mathrm{C}_{8}\right)$, leucine arylamidase, trypsin and naphthol-AS-BIphosphohydrolase.

The type strain is AHU1821 ${ }^{\mathrm{T}}$ (=DSM $45403^{\mathrm{T}}=\mathrm{NBRC}$ $106253^{\mathrm{T}}$ ), which was isolated from an ice wedge in the Fox permafrost tunnel, Alaska. Strain AHU1820 (=NBRC 106252 ) is a second strain of the species, isolated from the same source. 


\section{Acknowledgements}

We are grateful to Dr Daiichi Honjo for help with the nomenclature and to Dr Masanori Yasui for technical assistance with the scanning microscopic observations. This study was supported in part by a grant from the Institute for Fermentation, Osaka (IFO).

\section{References}

Adachi, K., Katsuta, A., Matsuda, S., Peng, X., Misawa, N., Shizuri, Y., Kroppenstedt, R. M., Yokota, A. \& Kasai, H. (2007). Smaragdicoccus niigatensis gen. nov., sp. nov., a novel member of the suborder Corynebacterineae. Int J Syst Evol Microbiol 57, 297-301.

Adékambi, T., Shinnick, T. M., Raoult, D. \& Drancourt, M. (2008). Complete $r p o B$ sequencing as a suitable supplement to DNA-DNA hybridization for bacterial species and genus delineation. Int J Syst Evol Microbiol 58, 1807-1814.

Butler, W. R., Floyd, M. M., Brown, J. M., Toney, S. R., Daneshvar, M. I., Cooksey, R. S., Carr, J., Steigerwalt, A. G. \& Charles, N. (2005). Novel mycolic acid-containing bacteria in the family Segniliparaceae fam. nov., including the genus Segniliparus gen. nov., with descriptions of Segniliparus rotundus sp. nov. and Segniliparus rugosus sp. nov. Int J Syst Evol Microbiol 55, 1615-1624.

Goodfellow, M. \& Maldonado, L. A. (2006). The families Dietziaceae, Gordoniaceae, Nocardiaceae and Tsukamurellaceae. In The Prokaryotes. A Handbook on the Biology of Bacteria, 3rd edn, vol. 3, pp. 843-888. Edited by M. Dworkin, S. Falkow, E. Rosenberg, K. H. Schleifer \& E. Stackebrandt. New York: Springer.

Gounot, A. M. \& Russell, N. J. (1999). Physiology of cold-adapted microorganisms. In Cold-adapted Organisms, pp. 33-55. Edited by R. Margesin \& F. Schinner. New York: Springer.

Katayama, T., Tanaka, M., Moriizumi, J., Nakamura, T., Brouchkov, A., Douglas, T. A., Fukuda, M., Tomita, F. \& Asano, K. (2007). Phylogenetic analysis of bacteria preserved in a permafrost ice wedge for 25,000 years. Appl Environ Microbiol 73, 2360-2363.

Katayama, T., Kato, T., Tanaka, M., Douglas, T. A., Brouchkov, A., Fukuda, M., Tomita, F. \& Asano, K. (2009). Glaciibacter superstes gen. nov., sp. nov., a novel member of the family Microbacteriaceae isolated from a permafrost ice wedge. Int J Syst Evol Microbiol 59, 482-486.

Keweloh, H. \& Heipieper, H. J. (1996). Trans unsaturated fatty acids in bacteria. Lipids 31, 129-137.

Lechevalier, M. P. \& Lechevalier, H. A. (1970). Chemical composition as a criterion in the classification of aerobic actinomycetes. Int J Syst Bacteriol 20, 435-443.

Minnikin, D. E., O’Donnell, A. G., Goodfellow, M., Alderson, G., Athalye, M., Schaal, A. \& Parlett, J. H. (1984). An integrated procedure for the extraction of bacterial isoprenoid quinones and polar lipids. J Microbiol Methods 2, 233-241.

Soddell, J. A., Stainsby, F. M., Eales, K. L., Kroppenstedt, R. M., Seviour, R. J. \& Goodfellow, M. (2006). Millisia brevis gen. nov., sp. nov., an actinomycete isolated from activated sludge foam. Int J Syst Evol Microbiol 56, 739-744.

Staneck, J. L. \& Roberts, G. D. (1974). Simplified approach to identification of aerobic actinomycetes by thin-layer chromatography. Appl Microbiol 28, 226-231.

Yano, I., Saito, K., Fukukawa, Y. \& Kusunose, M. (1972). Structural analysis of molecular species of nocardomycolic acids from Nocardia erythropolis by the combined system of gas chromatography and mass spectrometry. FEBS Lett 21, 215-219.

Zhi, X. Y., Li, W. J. \& Stackebrandt, E. (2009). An update of the structure and 16S rRNA gene sequence-based definition of higher ranks of the class Actinobacteria, with the proposal of two new suborders and four new families and emended descriptions of the existing higher taxa. Int J Syst Evol Microbiol 59, 589-608. 